\title{
QUEST FOR MUTUAL SCHOOL-COMMUNITY RELATIONSHIP IN NIGERIA: THE CRITICAL CENTRIFUGAL FORCES
}

\author{
Ige Akindele Matthew \\ Director of School Services, Ondo State Ministry of Education, Science And Technology, Akure, Nigeria \\ Email:deledivine@yahoo.co.uk
}

\begin{tabular}{|l|l|l} 
Diterima :01 Maret 2020 & Direvisi :29 April 2020 & Diterbitkan :07 Juli 2020
\end{tabular}

\begin{abstract}
Mutual school-community relationship is imperative in the educational system due to the associated benefits. One of the purposes of establishing a school is to serve the immediate community. A community also needs to monitor and supervise the schools located within it, attend to their needs, challenges, as well as monitor their progress, so that there will be effective management of the schools while the set objectives can be achieved. In this paper, critical forces pulling schools and communities apart (i.e. centrifugal forces) in Nigeria, such as theft of school properties, encroachment into school's land/territory, interference in school's activities, invasion of school by hoodlums, ritual killings, and obstruction of movement of staff, indiscipline of pupils/students and teachers, as well as the apathy of school to community's activities, are examined. To tackle the forces and achieve mutual school-community relationships, all hands must be on deck, particularly, by the parties to the school and community relationship. In this case, non-apathy of school to community activities, prevention of theft of school properties, non-interference of community members in school affairs, non-interference of parents and community in school affairs, among others, are recommended.
\end{abstract}

Keywords: School, community, school-community relationship, centrifugal force

\section{Abstrak}

Hubungan antara sekolah dan masyarakat sangat penting dalam sistem pendidikan karena manfaat yang ada di dalamnya. Salab satu tujuan pendirian sekolah adalab untuk melayani masyarakat yang berada di sekitarnya. Masyarakat juga perlu memantau dan mengawasi sekolah-sekolah yang berada disekelilingnya, memperbatikan kebutuban mereka, tantangan, serta memantau kemajuan mereka, sehingga akan tercipta manajemen sekolah yang efektif sementara tujuan yang ditetapkan juga dapat tercapai. Tulisan ini menganalisa kekuatan kritis yang memisabkan antara sekolah dan masyarakat (yaitu kekuatan sentrifugal) di Nigeria, seperti pencurian properti sekolah, gangguan lingkungan sekolah, campur tangan dalam kegiatan sekolah, invasi sekolah oleh preman, ritual pembunuban, gangguan akan aktivitas staf sekolah, ketidakdisiplinan siswa dan guru, serta sikap apatis sekolah terhadap kegiatan masyarakat. Untuk mengatasi kekuatan tersebut dan mencapai hubungan timbal balik sekolab-masyarakat, semua pibak harus bersinergi, terutama pihak-pibak sekolah dan bubungan dalam masyarakat. Sebagai solusi, ada beberapa kegiatan yang direkomendasikan, diantaranya tidak apatisnya sekolah akan kegiatan masyarakat, pencegahan pencurian properti sekolah, tidak adanya campur tangan anggota masyarakat dalam urusan sekolah, tidak adanya campur tangan orang tua dan masyarakat dalam urusan sekolah.

Kata Kunci: Sekolah, komunitas, bubungan sekolab-masyarakat, kekuatan Sentrifugal 


\section{Introduction}

Over the years, the establishment of schools/educational institutions has been a priority of government (at the federal, state, and local levels) in Nigeria. This is aimed at catering for the rising demand for education by the citizens, occasioned by the belief in it as the only antidote to ignorance, a catalyst to development; as well as the solution to the prevailing out-of-school children syndrome which has become a global phenomenon. The effort of government is however complemented by that of the private sector, where a lot of schools/institutions had also been established at the primary, secondary and tertiary levels. For examples, statistics revealed that as at 2017, there were 68, 471 Public Primary and 43, 507 Private Primary Schools; 13,157 Public Junior Secondary and 19, 256 Private Junior Secondary Schools; 9,015 Public Senior Secondary and 13,423 Private Senior Secondary Schools, in Nigeria ${ }^{1}$.

The establishment of schools/ educational/institutions is associated with the high-expectations from them, by the stakeholders. For example, they want the pupils/students to be academically and behaviourally upright, and the teachers to be highly committed to the job, among other expectations. However, school administrators are facing a lot of challenges in the daily management of their respective schools, such as the issue of indiscipline of pupils/students, the poor academic performance of pupils/students, insufficient and decay infrastructural facilities, insufficient teachers, cultism among teachers and pupils/students, just to mention a few. The growing complexity in the administration of schools, calls for the

1 Federal Ministry of Education, Nigeria Digest of Education Statistics (Nigeria: Federal Government Press, 2017). school administrators to relate with the stakeholders while trying to tackle the challenges, as it is rightly said that 'two heads are better than one' while a problem shared is half-solved. A community-school relationship is thus important in school administration.

According to Ojedele, through such a relationship, the school head will learn about the progress, development, problems, purposes, programs, and needs of the school $^{2}$. Bello also opined that the open relationship between a school and the community could bring about high opportunities that will allow community resources to be optimally utilized for school improvement ${ }^{3}$.

An atmosphere of the non-mutual relationship between a school and community will be difficult for the school's objectives to be achieved because of the distraction of the administrators. An atmosphere of distrust is also bound to develop which will endanger the academic growth and development of the pupils/students and make the school unsafe for children/pupils. Many parents may even feel reluctant to enroll their children in such school while many pupils/students may feel threatened and as a result, withdraw from such school or drop out completely. Nonmutual relationships between a school and the community could further make teachers unsafe in the community which may encourage their non-commitment to teach. It can also lead to high teacher turnover. Many teachers, could be as a result of

2 P $\quad \mathrm{K}$ Ojedele, 'Community--School Relations Challenges for School Administrators in the 21st Century', Educatnional Planning and Administration in the 21st Century Ondo NIEPA, 2000.

3 T. O. Bello, 'Public-Private Partnership, Infrastructural Development and Academic Goals Achievement of Nigerian Universities.', A Seminar Paper Presented at Universities of Ilorin on 25/6/2011 (University of Ilorin, 2011). 
unsafe/unfriendly communities, seek transfer to another school. Apart from constituting pressure on the agency in charge of the transfer of teachers, frequent transfer of teachers may harm the academic performance of children in the long run.

\section{School-Community Relationship, in Context}

School is defined as a place where children go, to be educated. It is also a planned social institution, acting as an instrument of the society, for teaching the young. School is an institution, established by members of society, to prepare children for useful growth and development in cognitive, affective, and psychomotor domains, as well as transmit the culture of society from generation to generation, to ensure its continued existence. It thus implies from the definitions that a school is established to serve the needs of the community where it is located, particularly, for its growth and development.

A school can be described as a 'public school' when it is financed and controlled mainly by the government (either at the local, state, or federal level). It can also be a 'private school' when it is financed by a non-governmental organization, Church, Mosque, or individual. An urban school is located in the city or urban area while a rural school is located in a remote or rural area. A school can also be potrayed as elementary, primary, secondary, or tertiary. In elementary school, early childhood education is provided for the children, either in Crèche, Kindergarten, or Nursery. In primary school, children receive primary education which comes before secondary education but after the pre-school education. It is the first stage of compulsory education in most parts of the world, Nigeria inclusive. The secondary school provides secondary education for children, after primary education, and before the tertiary education $^{4}$. Then, the tertiary institution provides tertiary education, which is beyond the secondary education, which is beyond the sondary education, and can be in a university, polytechnic, monotechnic, college of education, or other institution that is beyond the secondary level ${ }^{5}$.

Community is the group of people living together within the same locality, under the same government ${ }^{6}$. It is also described as a group of people in a given geographical area with common goals and aspirations.

School-community relationship is a series of planned activities through which a school seeks to learn about the community, inform the community about and interpret when necessary, the purposes, programs, problems, and evaluating school policies and progress ${ }^{7}$. It is also defined as mutual interaction between a school and community whereby they gain mutual help and understanding from each other, as well as being fully aware of one another's activities, policies, plans, programs, problems, progress, and failures ${ }^{8}$. In addition, Nnabuo and Emenalo, as cited in Abraham \& Ememe stated that schoolcommunity relationship is a genuine cooperation in planning and working for

\footnotetext{
${ }^{4}$ Nigeria, National Policy on Education (Federal Government Press, Federal Republic of Nigeria, 2004).

${ }^{5}$ Nigeria.

6 American Heritage Dictionary, American Heritage Dictionary, Information Systems, 2011, II $<$ https://www.ahdictionary.com/word/search.html ?q=education $>$.

7 D M Bortner, Public Relations for Public
} Schools (Schenkman Publishing Company, Distributed by General Learning Press [Morristown, N.J., $\quad$ 1972) $<$ https://books.google.co.id/books?id=2KQ0AAA AMAAJ $>$.

8 F O Afolabi, Basic Concepts in School Administration and Supervision, Ondo: Patrick Ade Press Nig. Ltd, 1998. 
the benefit of the school, with the public, giving as much as receiving ideas and resources ${ }^{9}$. Furthermore, according to Arthur and James, it refers to such a relationship involves a series of activities and media through which the school seeks to learn more, the purposes, programs, problems, and needs of the community. From whichever way it is viewed, a schoolcommunity relationship involves the flow of ideas between a school and the community where it is located, to ensure mutual understanding and effect teamwork, for the realization of educational institutional goals, and those of the community ${ }^{10}$.

\section{The Mutual Relationship of Community and School, in Nigeria's context}

There are benefits which a school can derive from the community where it is located. In Nigeria, there has been the involvement of the community in school affairs, which occurs mostly through the Parents-Teachers Association (PTA), which is one of the associations providing support for schools towards achieving their goals. In particular, the PTA provides opportunities for parents and teachers of a school to attend meetings where issues bordering on the discipline of the pupils, students, and the teachers, as well as the support for the school, are discussed. Parents in the forum take delight in visiting schools for dialogue with the teachers of their children, and to resolve disciplinary issues, challenges of the school, and how to provide support for the school. There are however reports of PTA

9 Nath Abraham and others, 'Effective School-Community Relations as a Key Performance Indicator for the Secondary School Administrator in Aba South District, Nigeria.', Journal of Curriculum and Teaching, 1.2 (2012), 21-26.

10 Arthur Bernard Moehlman and James A Van Zwoll, School Public Relations (Appleton-CenturyCrofts, 1957). contributions in schools in Nigeria, such as the provision of material support, particularly in the financing of PTA projects, which could be perimeter fence, block of classrooms, water borehole, and/or provision of labor for construction and maintenance of school buildings ${ }^{11}$. It is noteworthy that when teachers are insufficient in a school, particularly, in the core subjects such as English Language, Mathematics and the Sciences, the PTA often levy themselves, to offset the cost of recruitment of part-time teachers, to teach those subjects, so that the children will not suffer while the academic tone of the school will not diminish ${ }^{12}$. Also, the PTA provides learning materials for schools ${ }^{13}$ where the situation calls for urgent attention; as well as mediates between a school and the community when there is conflict ${ }^{14}$.

Also, in Nigeria, the School-Based Management Committee (SBMC) is a new program of government that is meant to assist in the management of schools across the country. Although in some schools, the SBMC is not active but there are reported cases of its functionality in most schools in the country, particularly, through the improvement of school infrastructure and mobilization of communities members to increase enrolment, especially in relation to girls; raising money for provision of

11 Máiréad Dunne and others, 'Adamawa State Primary Education Research: Access, Quality, and Outcomes, with Specific Reference to Gender', in Centre for International Education (University of Sussex, 2013)

<http://sro.sussex.ac.uk/id/eprint/46058/1/Adam awa_Primary_Education_Research-

executive_summary.pdf $>$.

12 Dunne and others.

13 Town Cape, National Assessment of Learning Achievement in Basic Education in Nigeria Junior Secondary Two', Universal Basic Education Commission (Nigeria, 2017) <https://ubeconline.com/Pre/2011 National Assessment of Learning Achievement in Basic Education (NALABE) Report.pdf $>$.

${ }^{14}$ Dunne and others. 
scholarships for pupils and students who are from less priviledge parents; provision of uniforms, sandals or textbooks for the girls ${ }^{15}$; mobilising community resources through voluntary contributions more than PTAs do, through levies, which are used for infrastructural development and provision of resources ${ }^{16}$; mobilizing communities, resulting in increasing of pupil enrolment and attendance ${ }^{17}$; improving mutual responsibility for improving education, including better reslations between schools and communities and local government and communities approaching government for support; improved teacher management, resulting in reduced absenteeism; and greater women's involvement, involving increased involvement by women (and in a few cases, children) in school improvement activities $^{18}$; provision of more teaching and learning resources ${ }^{19}$; increased feeling of ownership by communities ${ }^{20}$; and improved teacher behaviour, such as reductions in corporal punishment ${ }^{21}$.

Another way through which the communities have been supporting schools is through the establishment of school and provision of infrastructure, such as the laboratory blocks, donation of equipment and materials for effective teaching and learning in the schools ${ }^{22}$; free teaching of pupils/students by the parents ${ }^{23}$; tackling insecurity challenge through community policing of school $^{24}$; Poulsen, Little \& Lewis, Pinnock, Boulton et al., Dunne et al., obstruction of transfer of effective teachers from their territories to another, the discipline of pupils/students, information sharing and dissemination, monitoring of pupils and students progress, planning of curriculum $^{2526}$; provision of land for the construction of building for a school, as well as supervision of what is going on in school $^{27}$.

While communities are supporting schools in Nigeria, the schools are also supporting the communities in different ways. One of the ways through which schools have been helpful to the communities it is the permission it grants to

${ }^{21}$ Louise Wetheridge and others, Transforming Education for Girls in Tanzania: Endline Research Summary Report (Nigeria: Abuja, 2012) <https:/ / actionaid.org/publications/2013/transfor ming-education-girls-nigeria-endline-researchreport $>$.

${ }^{22}$ Michael U C Ejieh, 'Educational Quality and Community Involvement in Nigeria: Some Implications for Educational Planning', Journal of Social Sciences, 10.1 (2005), 43-48.

${ }^{23}$ Ejieh.

24 James Urwick, 'Determinants of the Private Costs of Primary and Early Childhood Education: Findings from Plateau State, Nigeria', International Journal of Educational Development, 22.2 (2002), 131-44.

${ }^{25}$ Ejieh.

${ }^{26}$ A J Ataine and V C Nkedishu, 'Relevance of School-Community Relations in the Development of Primary Education in Delta State, Nigeria'.

27 Ataine and Nkedishu. 
use their facilities, such as Hall, Chairs, playground, surroundings, for social functions, such as elections, making itself available for consultation to communities ${ }^{28}$; employment of young citizens of the communities as staff, thus helping to alleviate unemployment challenge.

\section{Reflections on the State of School- Community Relationship in Nigeria}

It is not doubtful that over the years, there have been concerted efforts to ensure mutual school-community relationship in Nigeria. However, there are some forces that are driving the wheel of progress backward. In Physics, Centrifugal force is a kind of force that pulls an object away from the center. In the context of this paper, these are the forces pulling schools and communities apart in Nigeria, including:

\section{Encroachment into school's land:}

It is a fact that a school needs a large piece of land for construction of buildings, sports fields, recreation centers, farms, and future expansion. Many public schools in Nigeria have lost part of their lands to encroachers and for different purposes, such as the construction of buildings, factories, farmlands, dumping of waste; access routes, buildings, factories, poultry farms, and cottage industries, driving of vehicles or herding animals ${ }^{29}$. Unfortunately, many schools now find it difficult to expand and offer sporting activities needed for the physical and psychological development of students/ pupils Although some schools have perimeter fence to protect their land from encroachers, those in the rural areas do find it difficult to construct fence because of the associated huge cost. Although cases of encroachment are often reported to the

\footnotetext{
${ }^{28}$ Ataine and Nkedishu.

${ }^{29}$ Boulton, Jackson, and DawnOliver.
}

Ministry of Education of States, due to bureaucratic bottleneck, decisions on such cases are usually slow while those in the courts are delayed by court procedures, occasioned by frequent adjournment. In some cases, members of the community take delight in passing through school premises, particularly those lacking perimeter fence thereby causing a distraction to the teaching-learning process and exposing the pupils/students to security treat.

In some schools, particularly in the rural areas and those lacking perimeter fence, domestic pets, such as dog, goat, hen, duck, among others enter school premises at will, to destroy farm or pollute the environment with excreta. In some cases, authorities of schools do give order to students/pupils to kill any pet caught within school premises while owners are at times asked to pay token (i.e. certain sum of money) for the release of such pets. The attitude of killing pets captured or release them after payment of the fee has however been observed to be uncomfortable for owners who prefer them to be released without any attached condition. The author also noticed that the sports field of many schools in Nigeria serves as a stadium for youths in the community, to play football and engage in other sporting activities, and even gambling. Quite unfortunate is the fact that school premises, particularly those without perimeter fence, now serve as hideouts for hoodlums to take marijuana and other dangerous drugs. There are even some of the hoodlums who will defecate on the floor of classrooms and destroy the wall of buildings when they are high as a result of their taking illicit drugs. On several occasions, school administrators do spend more hours at the beginning of a new week or term, to clean the lockers, chairs, and 
classrooms, already littered with hard drugs and feces.

\section{Theft of School's Properties:}

Case of theft of farm products, furniture, laboratory, and technical workshop facilities, among others in schools, are rampant and have been reported $^{30}$. Which are noticeable mostly in rural areas where security is porous. The author noticed that most Security Guards in schools these days are recruited from the immediate communities, aged, as well as incapacitated to perform the assigned task effectively. It can be imagined how a 70year old man or above will be recruited to provide security in a school. This is the situation in most schools in Nigeria. This unfortunate situation is being exacerbated by the growing unemployment level in the country. These old and incapacitated individuals just believe in staying within the school premises and collect their salaries at the end of the month, just to keep the body and soul together. Most of these individuals' misnamed security guards, often run for their dear lives anytime the armed robbers invade the school premises. Unfortunately, some are fond of colluding with members of communities to invade schools and steal valuable properties of schools.

\section{Interference in School's Activities:}

The negative reactions to disciplinary measures meted on pupils/ students are noticeable in many schools in Nigeria $^{31}$. It is a fact that parents have roles to play in the education of a child.

30 Musliudeen Adebayo, 'Hoodlums Invade Public Schools in Oyo, Destroy Properties Worth Millions of Naira', Daily Post, 2019 <https://dailypost.ng/2019/09/27/hoodlumsinvade-public-schools-oyo-destroy-propertiesworth-millions-naira/> [accessed 14 May 2019].

${ }^{31}$ Joshua Abong'o Okumbe, Human Resources Management: An Educational Perspective (Educational Development and Research Bureau, 2001).
Enforcing discipline of pupils/students is one of the duties of a school. At times, disciplinary measures meted on children, particularly, corporal punishments, such as flogging, suspension from school, withdrawal from school, call to pay for the damage (s), among others, are criticized and protested by parents/guardians. The author noticed that on several occasions, parents had led thugs to schools to beat teachers who flog their children. The wealthy ones among such parents/guardians do take school matters to court, to prove their wealth. It has also been noticed by the author that a community does wish to exercise control over the affairs of school (s) located within it, particularly during the admission of students, appointment of headteacher/ principal, workers, and teachers. Those communities often demand their shares of the slots, to prove that they are relevant. School heads are also often threatened by traditional rulers/chiefs for failure to satisfy their demands in the running of school affairs.

\section{Invasion of School by Hoodlums:}

There are reported cases of invasion of schools by hoodlums in different parts of Nigeria $^{32}$, which often lead to kidnapping, theft of properties of the teachers, pupils/ students, schools, as well as the rape of innocent female pupils/students and teachers, and ultimately, the withdrawal of pupils/students from schools. In Nigeria, it is unfortunate that the hoodlums consider schools' first point of contact anytime they wish to satisfy their sexual orgies, at the detriment of the innocent female pupils/

32 Bose Adelaja, 'Residents Raise Alarm over Invasion of Hoodlums in Public School', Varieties of English: Africa, South and Southeast Asiaanguardngr, 2013

<https://www.vanguardngr.com/2013/12/resident s-raise-alarm-invasion-hoodlums-public-school/> [accessed 3 July 2019]. 
students. It is disturbing that the men of the underworld will carry out these dastardly acts and go scot-free because of a lack of justice and failure of the security personnel to perform their duties.

\section{Ritual killings and obstruction of the movement of Staff:}

Nigeria is a country that is rich in culture. Ritual killings/and obstructive movement of staff, pupils/students are factors to contend with. There are reports of ritual killings in the literature ${ }^{33}$, most of which are greeted with demonstrations by pupils/students and result in loss of lives and properties (naijapoint.com; pulse.ng; www.thebbbuzz.com).

It has also been a norm in some communities for residents, particularly the non-indigenes and those that move at odd times and ignorant of the law forbidden movement at the specified time, to be apprehended and used for rituals, to appease the gods. In some communities, the issue of masquerade is a tradition that must be observed at a particular period of the year. The celebration of the festival is often associated with the order that citizens should stay indoor for a particular period. All these go a long way to set a community against schools.

Indiscipline of Pupils/Students and Teachers:

Ideally, pupils/students supposed to display and maintain high-level discipline as well as decorum within and outside school. There are reports of indiscipline of pupils and students' within and outside schools in

33 The Premium Times, 'How We Killed Final Year Female LASU Student', The Premium Times, 2020

<https://www.premiumtimesng.com/news/topnews/371181-how-we-killed-final-year-female-lasustudent-suspects.html $>$ [accessed 4 January 2020].
Nigeria $^{34}$. In the rural areas, pupils/students take delight in breaking the perimeter fence of schools, to sneak out of the school premises, so that they can enjoy the freedom which they cannot enjoy within the school. There are situations when pupils/students will encroach into community farms to harvest food crops. Many farmers often complain about the destruction of their farmlands by pupils/students who will not stay in schools but prefer to look for fruits and other farm products. It is not a doubt that teachers are held in high esteem, the parents and other stakeholders look at them as role models and those who will help to impact appropriate knowledge, skills, as well as good character traits on their children. It is disturbing that there are reported cases of teachers misdemeanors in Nigeria.

These days, teachers are involved in an immoral relationship with female students, buying and selling within school premises, smoking, consumption of alcohol, engaging male students into cultism, immorality in dressing, and involvement in examination malpractice, just to mention a few $^{35}$. The negative attitudes of pupils/students, as well as some teachers, have been giving the public a negative impression of the school. A school whose children are fond of winning laurels will be the toast of the community, ditto for a highly organized school with disciplined pupils, students, and teachers.

Oosthuzen emphasized that maintaining discipline is essential for

${ }^{34}$ A C Onyije and D O Ojedapo, 'Guidance and Counseling Services for Achieving Skills Development in Nigerian Secondary School System: The Problems', Journal of Technical Education Research and Development, 3.1 (2010), 49-56.

35 Alonge H.O and Ige A.M, 'Strategies for Tackling Examination Malpractices in Nigeria', Journal of Open Learning and Teacher Education, 2.1 (2015), 105-17. 
creating a positive school climate that is conducive for good academic performance ${ }^{36}$. Sonn supports that a school without effective discipline is unmanageable and often results in unmotivated and demoralized educators and learners, which in turn do lead to the poor academic performance of pupils/students ${ }^{37}$. Where a school is not organized, with noncommitted teachers and those who display indisciplinary behaviors, and where the academic performance of pupils/students is dwindling, this may set the community against the school. According to Nakpodia, in schools where discipline is a serious problem, for example, where pupils/students bully others, parents can transfer their children to better schools ${ }^{38}$.

\section{The apathy of School to Community's Activities:}

A school and community supposed to relate cordially. A school should not be passive in community activities. Both principal/headteacher and staff of a school supposed to attend community programs and contribute ideas to the growth and development of the community. Some school heads operate singly or feel unconcerned about the activities in their immediate community. Such schools cannot receive the blessing(s) of the community and will be treated as a pariah by the community members.

\section{Recommendations}

$36 \mathrm{~J}$ Kilonzo, 'Challenges Faced by Headteachers in the Management of Students' Indiscipline in Public Secondary Schools in Lamu County', Unpublished Med. Project, Kenyatta University, 2013.

${ }^{37}$ Brenda. Sonn, Discipline in Schools: Discipline in a Culture of Human Rights (Cape Town: Via Afrika, 1999).

38 Edward D Nakpodia, 'Teachers Disciplinary Approaches to Students Discipline Problems in Nigerian Secondary Schools', International NGO Journal, 5.6 (2010), 144-51.
Mutual

school-community relationship is imperative for the effective administration of a school. To achieve this feat calls for the adoption of certain strategies. First and foremost, the school principal should relate cordially with the community leaders, chiefs, and traditional rulers and discuss issues that can ensure peaceful and mutual co-existence. As the head of school, he should feel free to share with the traditional rulers and chiefs within the community, issues that are inimical to the smooth running of the school, rather than keeping these to themselves or limiting these to the involvement of the staff of the school alone.

Also, community members should not interfere in issues that are internal to school. School administrators and staff do consider it an insult to their integrity if members of the community interfere in their affairs when they have not been informed officially. Community leaders should warn their subjects and discourage them from indulging in this. There should also not be interference of parents/ guardians or community members in any case of discipline meted on disobedient pupils/students in schools.

It is a fact that ritual killing or any form of obstruction of the movement of the teacher and principal of school creates fear in their mind and leads to the feeling of insecurity within the particular community. Community leaders should, therefore, ensure that ritual killings, involving the use of human beings, are prevented and stopped out-rightly. Those caught in the act should be handed over to the law enforcement agent, and punished appropriately, to serve as a deterrent to others.

There is also the need for community leaders to regularly inform their subjects 
through meetings on the need to prevent their pests from encroaching into school territory. School management should however ensure that the school's territory is fenced with a central gate, to regulate control the inflow and outflow of students and staff, outsiders, as well as prevent entrance of pests and other domestic animals into school premises. Also, a security guard should be employed to control the gate. Such a guard should be monitored in the course of discharging the duties. The electric wire can be put on top of the fence to further scare the invaders from gaining entrance. Where it has become difficult to construct a fence around school due to huge cost, management of school can plant trees around the school or use bamboo to make a fence around it, to demarcate the school from the environment.

Moreover, in some communities, there are school materials in the homes of some members of the community, which were carted away through the activities of those that enter the premises illegally, particularly, during break or vacation period. The author who was in the past a teacher in a secondary school noticed that chairs and lockers which belongeth to students were found in the homes of some members of the community where the school was located, Ditto for school uniform and other school materials, which could be traced to the laxity of the security men in charge of the security maintenance in the school. Any case(s) of theft of the school's properties, should be reported to the school authority and law enforcement agent. When reporting a theft, remember to note the date, time, and location of the incident. If someone else witnessed the theft, ask for the person's full name, and contact information for the police report. Prompt reporting is an important factor in recovering stolen items and in catching the thief.

Also, the role of meeting in ensuring the peaceful coexistence of individuals cannot be overemphasized. Apart from the regular and normal PTA meetings in school, there should be a regular meeting of school management and community leaders where issues bordering on a non-mutual relationship can be discussed and resolutions or decisions arrived at. Traditional rulers can use town Cryer to invite his/her subjects to the palace, to discuss issues that are very paramount to the smooth management of the school. According to Afolabi, when facilities, such as school bus, hall, well-ventilated classrooms, library, open football/sports field, etc are adequately available and accessible to members of the community, the school-community relationship will be promoted $^{39}$.

\section{Conclusion}

Schools are saddled with the responsibility of training the children put in their care as well as build their leadership skills, in preparation for the future. Schools are however facing a lot of challenges. A community must imbibe measures to ensure peaceful co-existence with school(s) within its territory so that the objectives of such school(s) can be achieved. In the same vein, a school can carry out those measures so that peace can reign between it and the community where it is located. If the strategies discussed are imbibead by the school administrators and communities, there is high hope that mutual schoolcommunity relationship will be a reality and not a mirage in Nigeria. 


\section{References}

\section{Book}

Afolabi, F O, Basic Concepts in School Administration and Supervision, (Ondo: Patrick Ade Press Nig. Ltd, 1998)

Antoninus, M., Community Survey Report. Education Sector Support Programme in Nigeria, (Nigeria:Education Sector Support Programme in Nigeria, 2010)

Federal Ministry of Education, Nigeria Digest of Education Statistics (Nigeria: Federal Government Press, 2017)

Nigeria, National Policy on Education (Federal Government Press, Federal Republic of Nigeria, 2004)

Coinco, Emily, Women's Participation in SBMC within the Complex Socio-Cultural Context of Nigeria (ESSPIN, 2012)

Moehlman, Arthur Bernard, and James A Van Zwoll, School Public Relations (Appleton-Century-Crofts, 1957)

Sonn, Brenda., Discipline in Schools: Discipline in a Culture of Human Rights (Cape Town: Via Afrika, 1999)

Okumbe, Joshua Abong'o, Human Resources Management: An Educational Perspective (Educational Development and Research Bureau, 2001)

Pinnock, Helen, Education Sector Support Programme in Nigeria (Nigeria: Education Sector Support Programme in Nigeria, 2012)

\section{Journal}

Abraham, Nath, and others, 'Effective School-Community Relations as a Key Performance Indicator for the Secondary School Administrator in Aba South District, Nigeria.', Journal of Curriculum and Teaching, 1.2 (2012), 21-26

Adediran, Sulleiman, 'Assessment of Effectiveness of the School Based Management System in Bauchi, Katsina, Sokoto and Niger States, Nigeria', 2012, 3-102
$<$ https://www.academia.edu/120884 20/Assessment_of_Effectiveness_of _the_School_Based_Management_Sy stem_in_Bauchi_Katsina_Sokoto_an d_Niger_States_Nigeria_20082010_>

Alonge H.O, and Ige A.M, 'Strategies for Tackling Examination Malpractices in Nigeria', Journal of Open Learning and Teacher Education, 2.1 (2015), 10517

Alonge H.O, and Ige A.M, 'Strategies for Tackling Examination Malpractices in Nigeria', Journal of Open Learning and Teacher Education, 2.1 (2015), 10517

Ejieh, Michael U C, 'Educational Quality and Community Involvement in Nigeria: Some Implications for Educational Planning', Journal of Social Sciences, 10.1 (2005), 43-48

Nakpodia, Edward D, 'Teachers Disciplinary Approaches to Students Discipline Problems in Nigerian Secondary Schools', International NGO Journal, 5.6 (2010), 144-51

Urwick, James, 'Determinants of the Private Costs of Primary and Early Childhood Education: Findings from Plateau State, Nigeria', International Journal of Educational Development, 22.2 (2002), 131-44

Onyije, A C, and D O Ojedapo, 'Guidance and Counseling Services for Achieving Skills Development in Nigerian Secondary School System: The Problems', Journal of Technical Education Research and Development, 3.1 (2010), 49-56

\section{Newspapers and Magazines}

Adelaja, Bose, 'Residents Raise Alarm over Invasion of Hoodlums in Public School', Varieties of English: Africa, South and Southeast Asiaanguardngr, 2013

$<$ https://www.vanguardngr.com/20 13/12/residents-raise-alarminvasion-hoodlums-public-school/> 
\{accessed 3 July 2019\}

Adebayo, Musliudeen, 'Hoodlums Invade Public Schools in Oyo, Destroy Properties Worth Millions of Naira', Daily Post, 2019 <https://dailypost.ng/2019/09/27/ hoodlums-invade-public-schoolsoyo-destroy-properties-worthmillions-naira/> \{accessed 14 May $2019\}$

American Heritage Dictionary, American Heritage Dictionary, Information Systems, 2011, $<$ https://www.ahdictionary.com/wo $\mathrm{rd} /$ search.html?q=education $>$

Ataine, A J, and V C Nkedishu, 'Relevance of School-Community Relations in the Development of Primary Education in Delta State, Nigeria'

Bello, T. O., 'Public-Private Partnership, Infrastructural Development and Academic Goals Achievement of Nigerian Universities.', A Seminar Paper Presented at Universities of Ilorin on 25/6/2011 (University of Ilorin, 2011)

Bortner, D M, Public Relations for Public Schools (Schenkman Publishing Company, Distributed by General Learning Press [Morristown, N.J., 1972)

$<$ https://books.google.co.id/books?i $\mathrm{d}=2 \mathrm{KQOAAAAMAAJ}>$

Boulton, Diane, Peter Jackson, and DawnOliver, 'School Case-Study Reports - Kaduna, Kano and The Kwara States', Education Sector Support Programme in Nigeria (Nigeria, 2009), p. 12 $<$ https://www.google.com/url?sa $=\mathrm{t}$ $\& r c t=j \& q=\& e s r c=s \&$ source $=$ web\&c $\mathrm{d}=$ \&ved=2ahUKEwjphMT5xLrqAh WRWX0KHUaHArIQFjAAegQIAR AB\&url=https $\% 3 \mathrm{~A} \% 2 \mathrm{~F} \% 2 \mathrm{Fwww}$.es spin.org $\% 2$ Freports $\% 2$ Fdownload $\%$ 2F34-file-1253203219esspin_012_scho.pdf\&usg=AOvVaw 3nmuSX_Vt6k0NqXAK1ZV7c>

Dunne, Máiréad, Sara Humphreys, Moses
Dauda, Jiddere Kaibo, and Ayo Garuba, 'Adamawa State Primary Education Research: Access, Quality, and Outcomes, with Specific Reference to Gender', in Centre for International Education (University of Sussex, 2013) <http://sro.sussex.ac.uk/id/eprint/4 6058/1/Adamawa_Primary_Educati on_Research-

executive_summary.pdf $>$

Ojedele, P K, 'Community--School Relations Challenges for School Administrators in the 21st Century', Educatnional Planning and Administration in the 21st Century Ondo NIEPA, 2000

The Premium Times, 'How We Killed Final Year Female LASU Student', The Premium Times, 2020 $<$ https://www.premiumtimesng.com /news/top-news/371181-how-wekilled-final-year-female-lasu-studentsuspects.html> \{accessed 4 January $2020\}$

Town Cape, 'National Assessment of Learning Achievement in Basic Education in Nigeria Junior Secondary Two', Universal Basic Education Commission (Nigeria, 2017) $<$ https://ubeconline.com/Pre/2011 National Assessment of Learning Achievement in Basic Education (NALABE) Report.pdf $>$

Wetheridge, Louise, Oliver Kapaya, Elaine Unterhalter, and Jo Heslop, Transforming Education for Girls in Tanzania: Endline Research Summary Report (Nigeria: Abuja, 2012) $<$ https:/ /actionaid.org/publications/ 2013/transforming-education-girlsnigeria-endline-research-report>

\section{Thesis}

Kilonzo, J, 'Challenges Faced by Headteachers in the Management of Students' Indiscipline in Public Secondary Schools in Lamu County', Unpublished Med. Project, Kenyatta University, 2013 